\title{
EVALUASI KONDISI KUALITAS AIR BERDASARKAN DAMPAK BEBAN PENCEMARAN TERHADAP SEBARAN OKSIGEN TERLARUT DI SUNGAI GUNUNG PASANG KABUPATEN JEMBER
}

\author{
Elida Novita $^{1^{*} \text {, }}$, Bawon Rani Yudhika Anwar ${ }^{1}$, Hendra Andiananta Pradana ${ }^{2)}$ \\ ${ }^{1)}$ Teknik Pertanian, Fakultas Teknologi Pertanian, Universitas Jember \\ Jl. Kalimantan No. 37, Jember 68121, Indonesia \\ ${ }^{2)}$ Magister Pengelolaan Sumber Daya Alam dan Lingkungan, Pascasarjana, Universitas Jember \\ Jl. Kalimantan No. 37, Jember 68121, Indonesia \\ *Email:elida_novita.ftp@unej.ac.id
}

\section{ABSTRACT \\ WATER QUALITY EVALUATION ON POLLUTION LOAD IMPACT TO DISSOLVED OXYGEN DISTRIBUTION IN THE GUNUNG PASANG RIVER, JEMBER REGENCY}

Gunung Pasang River is as raw water supply for the human activity. However, it is utilized as waste disposal from community activities, agro-tourism, and rubber factories. These activities have the potential to reduce water river quality. The efforts to river pollution prevention that can be taken are to examine for capacity of the rivers to reduce pollutant naturally. The research focused to analysis the pollution load, oxygen dissolved distribution (deoxygenation and reoxygenation rate), and the total pollution load of the Gunung Pasang river utilized the Streeter-Phelps formula. The study was conducted in November - December in 2019 at the Gunung Pasang River with a river length of $300 \mathrm{~m}$ which was divided into 3 segments with 4 monitoring points (GP01, GP02, GP03, GP04). Analysis of the parameters i.e. DO and BOD to measure the water quality degradation in the river and the resulting graph of oxygen reduction. The method refers to Minister of the Environment Decree no. 110/2003. The results showed that the average pollution load value was $6.32 \mathrm{~kg} /$ day. The range of deoxygenation and reoxygenation rates is $2.67-5.36 \mathrm{mg} / \mathrm{L}$.day and 32.77 - $64.71 \mathrm{mg} / \mathrm{L}$.day respectively. The Reoxygenation rate was greater than deoxygenation. This phenomenon reflected that the Gunung Pasang River has a good self - purification performance. The average pollution load capacity of the river is $2.17 \mathrm{~kg} /$ day.

Keywords: total pollution capacity; oxygen distribution; self - purification; water quality monitoring.

\section{PENDAhUluan}

\subsection{Latar Belakang}

Rendahnya status mutu air di beberapa sungai di Jawa Timur menjadi tantangan dalam keberlanjutan pemanfaatan sumber air permukaan. Merujuk pada hasil kajian Pradana et al. (2020), hasil evaluasi kualitas air Sungai Bedadung di Kabupaten Jember Provinsi Jawa Timur dalam kategori tercemar ringan hingga sedang berdasarkan metode indeks pencemaran (IP). Sungai Bedadung merupakan salah satu badan air terbesar di DAS Bedadung yang akan bekontribusi terhadap nilai IKA di Provinsi Jawa Timur. Adapun hasil kajian (Pradana et al. 2020), mengemukakan bahwa nilai indeks 
pencemaran Sungai Bedadung dalam kategori tercemar ringan. Aktivitas pada bagian hulu sungai akan mempengaruhi kualitas air pada bagian hilir sungai. Sejalan dengan fenomena tersebut akumulasi beban pencemaran pada bagian hulu dan anak sungai akan menurunkan kualitas air sungai bagian hilir (Pangestu et al. 2017; Pradana et al. 2020).

Sungai Gunung Pasang merupakan salah satu anak Sungai Bedadung di Kabupaten Jember. Desa Suci Gunung Pasang, Kecamatan Panti dialiri oleh Sungai Gunung Pasang. Sungai Gunung Pasang dimanfaatkan oleh masyarakat untuk kegiatan sehari - hari seperti MCK, pembuangan limbah rumah tangga, limbah perkebunan dan sebagai pembuangan air limbah oleh sebuah industri pabrik pengolahan karet. Selain itu, pada bagian hilir Sungai Gunung Pasang dimanfaatkan sebagai agrowisata. Aktivitas tersebut berpotensi menurunkan kualitas air sungai dan mengganggu ekosistem perairan. Risiko terjadinya pencemaran pada badan air akan memengaruhi kemampuan alamiah untuk mereduksi bahan pencemar suatu badan air (Rahayu et al., 2018). Menurut Kepmen LH No 113/2003, daya tampung sungai ialah kemampuan badan air untuk menerima masukan bahan pencemar tanpa menimbulkan fenomena pencemaran pada air tersebut.

Menurut DLH Kabupaten Jember (2007), mengemukakan bahwa belum terdapat data mengenai daya tampung beban pencemaran sungai Gunung Pasang, sehingga tidak ada tolak ukur bagi masyarakat untuk mengatahui kapasitas Sungai Gunung Pasang dalam menerima beban pencemaran. Kajian pemeriksaan daya tampung beban pencemaran sebelumnya sudah dikaji pada Sungai Bedadung sebagai sungai utama yang akan memperoleh aliran dari Sungai Gunung Pasang (Wahyuningsih et al., 2019; Pradana et al., 2019). Oleh karena itu diperlukan analisis daya tampung sungai untuk mengetahui kemampuan sungai dalam menerima bahan pencemar yang masih bisa ditampung dan dapat diuraikan secara alami. Prinsip StreeterPhelps merupakan salah satu metode analisis nilai daya tampung sungai terhadap bahan pencemar organik berdasarkan parameter DO, BOD, suhu, dan debit (Marganingrum et al., 2018: Pradana et al., 2019). Penggunaan metode tersebut dalam menilai kualitas sumber air permukaan tercantum pada Kepmen LH No. 110 Tahun 2003. Peraturan tersebut menjelaskan bahwa monitoring kualitas air melalui pendekatan distribusi oksigen dan paparan bahan organik. Daya tampung beban pencemaran menjadi salah satu pertimbangan dalam pengelolaan dan perlindungan kualitas sumber air. Pendekatan tersebut digunakan untuk mengidentifikasi pemurnian alami (self purification) pada suatu badan air. Penelitian ini bertujuan untuk mengidentifikasi beban pencemaran, laju deoksigenasi dan reoksigenasi, serta kapasitas maksimum beban pencemaran Sungai Gunung Pasang berdasarkan formula Streeter-Phelps.

\section{METODOLOGI}

\subsection{Perlengkapan dan Material}

Perlengkapan yang dimanfaatkan terdiri atas tali, baji, GPS, meteran gulungan, current meter merek Seba Hydrometrie F1 Universal, termometer, botol contoh air, alat pendingin portable, botol winkler $125 \mathrm{~mL}$ merek pyrex, erlenmeyer $250 \mathrm{~mL}$ merek pyrex, satu unit pompa vakum, pipet volumetrik $100 \mathrm{~mL}$, turbidity meter, $\mathrm{pH}$ meter, inkubator, pemanas berupa oven, desikator, neraca analitik digital, dan cangkir porselin serta alumunium. Mateial penelitian terdiri atas contoh air Sungai Gunung Pasang yang diambil pada beberapa titik pengamatan, kertas saring diameter $0,45 \mu \mathrm{m}$, larutan 
$\mathrm{Na}_{2} \mathrm{~S}_{2} \mathrm{O}_{3} 0,025 \mathrm{~N}, \mathrm{H}_{2} \mathrm{SO}_{4} 20 \mathrm{~N}, \mathrm{MnSO}_{4}$ 40\%, Alkali-iodida Azida, amilum 5\%, dan air suling bebas ion.

\subsection{Metode}

A. Pengambilan sampel air sungai

Pengambilan sampel air berdasarkan metode grab sampling. Metode tersebut dilakukan dengan pengambilan contoh air pada waktu tertentu secara sesaat (Pradana et al., 2019). Pengambilan sampel air dilakukan di empat titik (GP01, GP02, GP03, GP04) pada tanggal 19, 26, dan 29 November 2019 pukul 13.00 - 15.00 WIB. Lokasi penelitian direpresentasikan pada peta di Gambar 1.

\section{B. Pengukuran kualitas air sungai}

Contoh air akan dianalisis mutunya berdasarkan komponen yaitu oksigen terlarut (OT atau DO) dan kebutuhan oksigen biokimia (BOD) sebagai data input pada formula Streeter - Phelps (Kepmen LH No. 110 (2003). Nilai DO dilakukan dengan metode titrasi. Selanjutnya nilai BOD diperoleh dari selisi $\mathrm{DO}_{0}$ dengan $\mathrm{DO}_{5}$ yang diinkubasi pada suhu $20^{\circ} \mathrm{C}$. Proses penguraian membutuhkan waktu dua hari untuk mengoksidasi zat orgnik sebesar $50 \%$, lima hari sebesar $75 \%$ dan dua puluh hari sebesar $100 \%$ dengan temperatur $20^{\circ} \mathrm{C}$ (SNI, 2009).
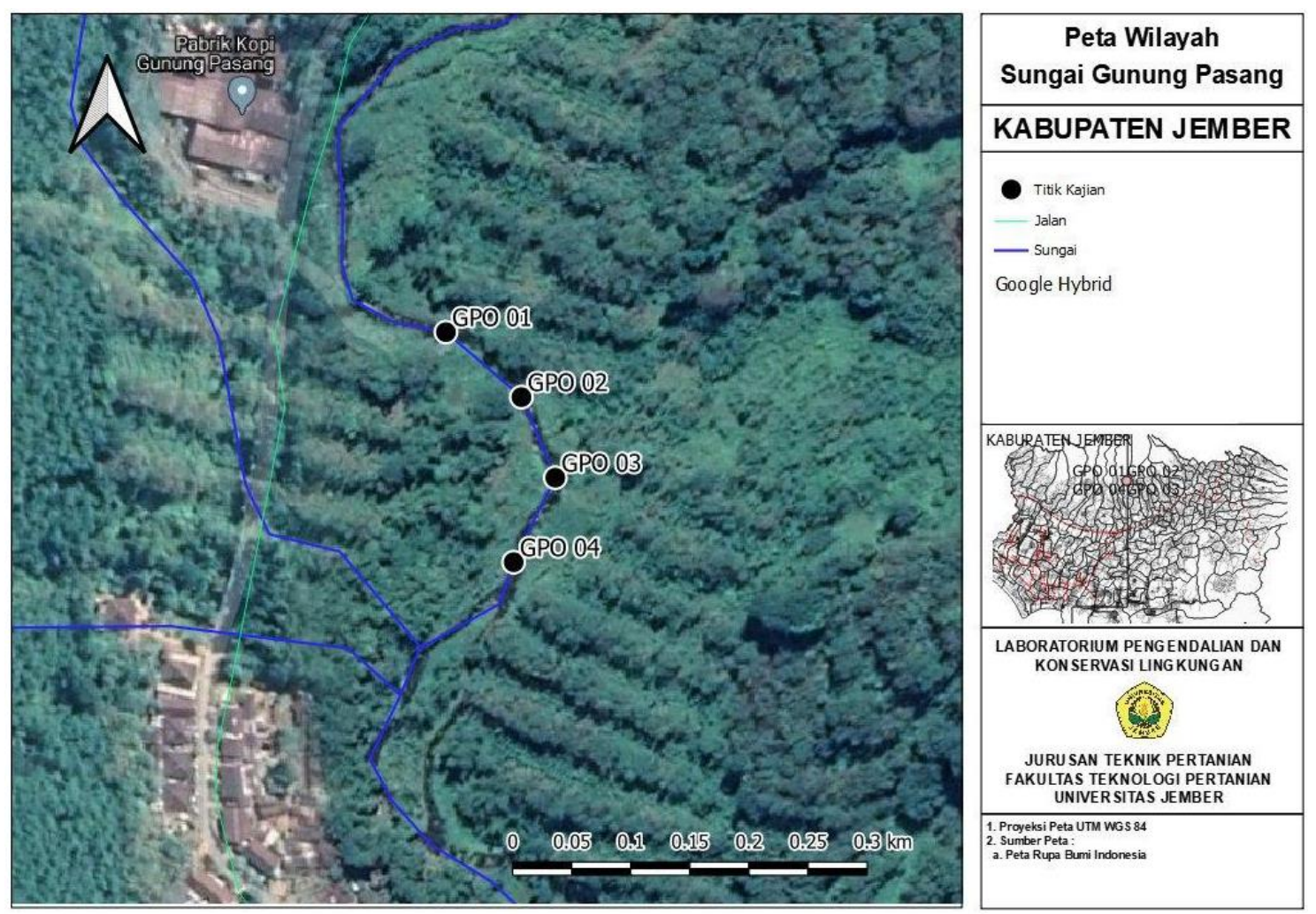

Gambar 1.

Peta lokasi pengambilan debit dan contoh air

\section{Analisis debit Sungai Gunung Pasang}

Kajian pengukuran debit sungai dilakukan untuk mengetahui kuantitas air yang mengalir per satuan waktu pada setiap segmen. Pendekatan yang digunakan untuk mengukur debit air yaitu perkalian antara luas penampang dengan kecematan aliran. Kecapatan aliran air diukur dengan menggunakan current meter. Pelaksanaan pengukuran debit, 
terlebih dahulu dilakukan pembuatan profil sungai. Debit sungai dihitung menggunakan Persamaan 1 (SNI, 2015; Pradana et al., 2019).

$$
\mathrm{Q}=\mathrm{V} \times \mathrm{A}
$$

Dimana:

$$
\begin{aligned}
& \mathrm{Q}=\text { debit air }\left(\mathrm{m}^{3} / \text { detik }\right) \\
& \mathrm{V}=\operatorname{kecepatan} \operatorname{arus}(\mathrm{m} / \mathrm{s}) \\
& \mathrm{A}=\text { luas penampang }\left(\mathrm{m}^{3}\right)
\end{aligned}
$$

D. Perhitungan beban pencemaran sungai

Menurut Pangestu et al. (2017), menjelaskan persamaan untuk menghitung beban pencemaran dapat dilihat pada (Persamaan 2).

$$
\mathrm{BP}=\mathrm{Q} \times \mathrm{C}
$$

Dimana:

$\mathrm{BP}=$ Beban pencemar (ton/hari atau $\mathrm{kg} / \mathrm{hari}$ )

$\mathrm{Q}=$ Debit di sungai $\left(\mathrm{m}^{3} / \mathrm{s}\right)$

$\mathrm{C}=$ Konsentrasi polutan pada air limbah (mg/L)

1. Perhitungan laju deokisigenasi

Perhitungan laju deoksigenasi akibat paparan bahan organik pada perairan dapat dinyatakan dengan persamaan persamaan 3. Menurut Haidar et al., (2013) dan Huang et al., (2017), nilai $K_{D}$ (konstanta deoksigenasi atau dekomposisi bahan organik) diperoleh dari persamaan Hydroscience (1917) yang dapat dilihat pada persamaan 4 .

$$
\mathrm{rD}=\mathrm{K}_{\mathrm{D}, \mathrm{T}} \times \mathrm{L}_{\mathrm{t}}=\mathrm{K}_{\mathrm{D}} \cdot(1.047)^{\mathrm{T}-20} \times \mathrm{L}_{\mathrm{t}}
$$

$$
\mathrm{K}_{\mathrm{D}}=0,3\left(\frac{\mathrm{H}}{0,8}\right)^{-0,434}
$$

Dimana:

$\mathrm{r}_{\mathrm{D}}=$ Laju deoksigenasi

$\mathrm{K}_{\mathrm{D}}=$ konstanta deoksigenasi

$\mathrm{Lt}=\mathrm{BOD}$ residual pada saat $\mathrm{t}$

2. Perhitungan laju reoksigenasi
Rumus yang digunakan untuk menghitung proses peningkatan oksigen terlarut (reoksigenasi) dapat dilihat pada persamaan 5. Nilai $K_{R}$ diperoleh dari formula O'Cornor dan Dobbins disajikan pada persamaan 6 .

$$
\begin{aligned}
& \mathrm{r}_{\mathrm{R}}=\mathrm{K}_{\mathrm{R}, \mathrm{T}} \times \mathrm{D}=\left(\mathrm{K}_{\mathrm{R}}(1.016)^{\mathrm{T}-20}\right) \times\left(\mathrm{DO}_{\mathrm{g}}-\mathrm{DO}_{\mathrm{act}}\right) \\
& \mathrm{K}_{\mathrm{R}}=\frac{294\left(\mathrm{D}_{\mathrm{LT}} \times \mathrm{V}\right)^{1 / 2}}{\mathrm{H}^{\mathbb{8} / 2}}
\end{aligned}
$$

Dimana:

$\mathrm{r}_{\mathrm{R}}=$ laju reoksigenasi (miligram/Liter.hari)

$\mathrm{D}=$ Oksigen terlarut yang defisit (miligram/Liter)

$\mathrm{DO}_{\mathrm{s}}=$ Kandungan dissolved oxygen saturasi (miligram/Liter)

$\mathrm{DO}_{\text {act }}=$ Konsentrasi dissolved oxygen air sungai (miligram/Liter)

$\mathrm{T}=$ Suhu air sungai $\left({ }^{0} \mathrm{C}\right)$

$\mathrm{V} \quad=$ Rerata laju aliran air $\left(\mathrm{m}^{2} / \mathrm{s}\right)$

$\mathrm{H}=$ Rerata ketinggian atau kedalaman air pada sungai (meter) $\mathrm{D}_{\mathrm{LT}}=$ Koefisien kondisi oksigen pada suhu $\mathrm{T}^{0} \mathrm{C}$ (meter ${ }^{2}$ per hari)

Distribusi oksigen akan mempengaruhi dekomposisi bahan organik pada perairan. Fenomena ini akan menimbulkan Defisit oksigen (Dc). Defisit oksigen dan mempengaruhi daya tampung beban pencemaran sungai dalam mereduksi bahan organik hingga mencapai dalam kondisi perairan semula. Formula $7-10$ adalah formula untuk mengetahui nilai Dc (Kepmen LH No. 110 (2003).

$$
\begin{aligned}
\mathrm{D}_{\mathrm{t}} & =\frac{\mathrm{K}_{\mathrm{D}} \cdot \mathrm{L}_{0}}{\mathrm{~K}_{\mathrm{R}}-\mathrm{K}_{\mathrm{D}}}\left(\mathrm{e}^{-\mathrm{k}^{\prime} \mathrm{t}}-\mathrm{e}^{\left.-\mathrm{k}^{\prime} 2 \mathrm{t}\right)}+\mathrm{D}_{\mathrm{o}} \mathrm{e}^{-\mathrm{k}^{\prime} \mathrm{t}}(7)\right. \\
\mathrm{D}_{\mathrm{c}} & =\frac{\mathrm{K}_{\mathrm{D}}}{\mathrm{K}_{\mathrm{R}}} \mathrm{L}_{\mathrm{o}} \mathrm{e}^{-\mathrm{KD} \cdot \mathrm{tc}} \\
\mathrm{t}_{\mathrm{c}} & =\frac{1}{\mathrm{~K}_{\mathrm{R}}-\mathrm{K}_{\mathrm{D}}} \operatorname{In} \frac{\mathrm{K}_{\mathrm{R}}}{\mathrm{K}_{\mathrm{D}}}\left\{1\left\{\frac{\mathrm{D}_{\mathrm{o}}\left(\mathrm{K}_{\mathrm{R}}-\mathrm{K}_{\mathrm{D}}\right)}{\mathrm{K}_{\mathrm{D}}-\mathrm{L}_{\mathrm{o}}}\right\}\right\} \\
\mathrm{x}_{\mathrm{c}} & =\mathrm{t}_{\mathrm{c}} \cdot \mathrm{v}
\end{aligned}
$$


Keterangan :

$t_{c}=$ waktu kritis (hari)

$x_{c}=$ Jarak kritis $(\mathrm{km})$

$D_{o}=$ defisit oksigen pada keadaan awal $(\mathrm{mg} / \mathrm{L})$

$L_{\circ}=$ BOD $^{5}{ }_{20}($ miligram $/ \mathrm{L})$

$K_{D}=$ Nilai ketetapan deoksigenasi (1/hari)

$K_{R}=$ Nilai ketetapan reoksigenasi (1/hari)

$v=$ kecepatan aliran air sungai $(\mathrm{km} / \mathrm{hari})$

\section{HASIL DAN PEMBAHASAN}

\subsection{Kondisi Mutu Air Sungai Gunung Pasang}

Beban pencemaran adalah perkalian antara besarnya debit aliran (Q) sungai dengan konsentrasi BOD (mg/L) yang terdapat pada aliran sungai. Beban pencemar pada Sungai Gunung Pasang berasal dari limbah industri yang berupa air limbah dan padat serta aktivitas masyarakat yang menghasilkan limbah detergen, shampo, sabun, dan limbah yang berasal dari perkebunan.
Merujuk pada Tabel 1 menunjukkan bahwa titik GP02 memiliki beban pencemaran tertinggi yaitu sebesar 8,12 $\mathrm{kg} / \mathrm{hari}$, yang diakibatkan oleh tingginya konsentrasi BOD dan debit dengan nilai secara berurutan yaitu $0,80 \mathrm{mg} / \mathrm{L}$ dan 117,6 L/s. Secara umum besarnya beban pencemaran berbanding lurus terhadap debit dan kandungan bahan organik pada badan air (Putra et al., 2017; Wang et al., 2018). Kajian lainnya menyebutkan besarnya debit dan kosentrasi nilai BOD mengakibatkan besarnya nilai beban pencemaran (Pradana et al., 2019). Kondisi ini serupa dengan fenomena fluktuasi nilai beban pencemaran di Sungai Gunung Pasang pada beberapa titik pemeriksaan. Pada titik pantau GP 03 dan 04 memiliki nilai debit yang lebih rendah daripada titik pengamatan GP01 dan 02. Kondisi tersebut kemungkinan adanya halangan baik berupa sampah atau pendangkalan pada profil hidrolik sungai. Kondisi tersebut berdampak pada rendahnya nilai beban pencemaran pada lokasi pengamatan hilir atau GP04.

Tabel 1. Data Debit, Konsentrasi Pencemar (BOD) dan Beban Pencemaran Sungai Gunung Pasang

\begin{tabular}{lccc}
\hline Titik Pantau & $\begin{array}{c}\text { Debit } \\
\text { (liter/detik) }\end{array}$ & $\begin{array}{c}\text { Konsentrasi } \\
\text { BOD }(\mathbf{m g} / \mathbf{L})\end{array}$ & $\begin{array}{c}\text { Beban Pencemaran } \\
\text { (kg/hari) }\end{array}$ \\
\hline GP01 & 105,36 & 0,75 & 6,85 \\
GP02 & 117,96 & 0,80 & 8,15 \\
GP03 & 100,32 & 0,64 & 5,58 \\
GP04 & 100,91 & 0,54 & 4,71 \\
\hline Rata-Rata & 106,14 & 0,68 & 6,32 \\
\hline
\end{tabular}

Titik pantau GP04 memiliki nilai beban pencemaran yang paling rendah. Fenomena ini dikarenakan konsentrasi BOD sebesar 0,54 $\mathrm{mg} / \mathrm{L}$. Penurunan tersebut disebabkan oleh konsentrasi pencemar dan debit yang dimiliki titik GP04 sangat rendah di sepanjang titik lokasi penelitian. Kecilnya debit akan mempengaruhi kemampuan air untuk menguraikan bahan organik yang masuk. Jika nilai konsentrasi BOD dan debit air tinggi maka nilai beban pencemarannya akan besar. Merujuk pada Yustiani et al., (2018), menjelaskan jika fluktuasi nilai BOD dan debit mempengaruhi tinggi rendahnya beban pencemaran pada badan air. 
Rata-rata nilai beban pencemaran Sungai Gunung Pasang adalah sebesar $6,32 \mathrm{~kg} / \mathrm{hari}$. Adapun beberapa faktor yang mempengaruhi fluktuasi beban pencemaran selain profil sungai adalah sumber pencemaran seperti aktivitas MCK dan kemungkinan air limbah dari aktivitas non domestik di Sungai Gunung Pasang. Merujuk pada Permen LH No. 1 (2010), upaya pencegahan penurunan kualitas air sungai dapat dilakukan dengan pengendalian buangan limbah dari sumber pencemaran. Kedua karakteristik sumber bahan pencemar tersebut akan berdampak pada penurunan kualitas air sungai akibat bertambahnya bahan pencemar organik maupun anorganik.

\subsection{Analisis Distribusi Oksigen (Laju Deoksigenasi dan Reoksigenasi)}

Lamanya perubahan nilai $\mathrm{O}_{2}$ terlarut pada suatu badan air akibat masuknya bahan pencemar dan atau penggunaan oksigen oleh mikrorganisme perairan didefinisikan sebagai laju penurunan kandungan oksigen (deoksigenasi). Laju deoksigenasi dipengaruhi oleh konstanta dekomposisi $\left(K_{\mathrm{D}}\right)$, BOD yang berada di badan air (Lt) dan nilai BOD. Nilai konstanta dekomposisi $\left(K_{\mathrm{D}}\right)$ merepresentasikan kecepatan degradasi bahan organik secara biokimia oleh bantuan mikroorganisme aerob pada sumber air permukaan (Abukilla, 2012).

Besar laju deoksigenasi dan laju reoksigenasi Sungai Gunung Pasang Sungai di wilayah kajian ditunjukkan pada Tabel 2 dan 3. Nilai tertinggi laju deoksigenasi pada titik GP02 adalah 5,36 (mg/L.hari). Tingginya $r_{D}$ pada titik GP02 dipengaruhi oleh nilai konsentrasi BOD yang ada di badan air (Lt) tertinggi sebesar 2,87 mg/L. Selanjutnya tingginya nilai $K_{D}$ pada titik pantau GP02 sebesar 1,61/hari akibat dari kedalaman yang mempengaruhi kehidupan mikroba dan konsentrai BOD 0,80 mg/L.

Besarnya $K_{D}$ di perairan bergantung pada kedalaman sungai $(H)$. Menurut (Yustiani et al., 2018) profil hidrolik sungai yang dalam mempengaruhi entitas mikroorganisme. Profil hidrolik sungai yang dalam dan tergenang air memiliki kandungan oksigen terlarut yang rendah. Kondisi tersebut menurunkan pasokan oksigen yang dapat dimanfaatkan oleh mikroorganisme perairan dangkal. Konsekuensi yang akan mungkin timbul adalah menurunkan jumlah mikroorganisme yang hidup sehingga dapat meningkatkan nilai $K_{D}$ suatu perairan. Selain faktor kedalaman sungai yang mempengaruhi kehidupan mikroba dalam menentukan nilai kecepatan dekomposisi $\left(\mathrm{K}_{\mathrm{D}}\right)$, faktor lain yang menjadi penentu laju deoksigenasi adalah konsentrasi bahan organik yang mudah terurai pada badan air sungai. Semakin dangkal sungai maka semakin banyak oksigennya sehingga mikroorganisme yang ada didalam air semakin banyak dan meningkatkan laju deoksigenasi. Hal tersebut sesuai dengan pernyataan Sugianti dan Astuti (2018) dan Sinaga et al., (2016), bahwa profil hidrolik suatu sungai berpengaruh terhadap keberadaan mikroorganisme yang ada di dalamnya. Kondisi profil hidrolik sungai yang dalam berdampak pada minimnya kandungan oksigen terlarut. Hal tersebut sebanding dengan nilai konsentrasi BOD di badan air (Lt) yang juga tinggi, akibatnya $r_{D}$ meningkat. Pada titik GP02 memiliki ratarata nilai kedalaman yang kecil dari titik pantau GP01, GP03, dan GP04 sehingga menyebabkan nilai $\mathrm{kD}$ pada titik GP02 meningkat.

Laju deoksigenasi (rD) paling tinggi terdapat pada titik pemantauan GP04 sebesar 2,67 mg/L. Profil hidrolik sungai yang cukup dalam oksigen terlarut berkurang sehingga mikroorganisme dalam sungai juga berkurang. Asumsi ini didukung berdasarkan hasil kajian yang menunjukkan bahwa nilai konsentrasi BOD di badan air (Lt) terendah yaitu 
sebesar 1,38 mg/L dan nilai konsentrasi BOD yang paling rendah dibanding dengan titik lokasi sebelumnya yaitu sebesar $0,54 \mathrm{mg} / \mathrm{L}$ menyebabkan nilai laju deoksigenasi $(\mathrm{rD})$ rendah.

Laju reoksigenasi menunjukkan kecepatan penyediaan oksigen yang diperoleh dari atmosfer ke dalam sungai. Nilai reoksigenasi paling tinggi yakni pada lokasi GP02 sebesar 64,71 mg/L.hari (Tabel 3). Nilai ketetapatan reoksigenasi (Kr) dan $\mathrm{O}_{2}$ terlarut yang defisit (D) mempengaruhi laju reoksigenasi. Jika nilai D tinggi maka nilai laju reoksigenasinya tinggi pula. Besarnya nilai $\mathrm{D}$ diperoleh akibat tingginya hasil pengurangan oksigen yang diperoleh dari nilai suhu perairan (Wahyuningsih et al., 2020; Pradana et al. 2019). Nilai Kr dan nilai D titik Pantau GP02 tinggi sebesar 18,76/hari dan 3,24 mg/L. Nilai tersebut megakibatkan laju reoksigenasi di titik pemantauan GP02 tinggi. Nilai $\mathrm{Kr}$ dan D juga dipengaruhi oleh rerata kecepatan aliran dan profil hidrolik sungai pada titik pantau GP02, secara berurutan yaitu 0,12 $\mathrm{m} / \mathrm{s}$ dan $0,18 \mathrm{~m} / \mathrm{s}$. Tingginya nilai ketetapan reoksigenasi akibat profil hidrolik sungai yang dangkal dan aliran air pada sungai yang cepat (Pradana et al., 2019). Aliran dari sungai yang dangkal mengakibatkan turbulensi sehingga laju reoksigenasinya semakin tinggi. Nilai laju reoksigenasi paling sedikit terdapat pada titik pengamatan GP04 yakni 33,75
mg/L.hari. Konsekuensi tersebut ada sebab pada lokasi pemantauan di GP04 memiliki nilai $\mathrm{D}$ yang rendah sebesar 1,18 $\mathrm{mg} / \mathrm{L}$. Selain itu, nilai kecepatan aliran dan kedalaman sungai pada titik pemeriksaan GP04 secara berurutan yaitu 0,17 meter dan 0,19 m/ds. Kecapatan arus air pada kondisi profil hidrolik badan air yang cukup dalam pada umumnya lebih tenang sehingga nilai reoksigenasinya cenderung lebih kecil.

Fluktuasi nilai konstanta deoksigenasi dan reoksigenasi dipengaruhi oleh kondisi alam pada lokasi pengamatan. Faktor faktor tersebut terdiri atas debit sungai, jumlah bahan pencemar yang masuk ke sungai, serta perubahan suhu perairan. Jika kecepatan aliran tinggi dan profil hidrolik sungai yang dangkal maka nilai konstanta reoksigenasinya juga besar. (Yustiani et al., 2019). Keuntungan yang akan diperoleh apabila laju reoksigenasinya besar maka paparan oksigen terlarut pada badan air tersebut relatif cukup dalam dekomposisi bahan organik secara alami di Sungai Gunung Pasang. Pernyataan tersebut didukung dengan adanya perbandingan hasil perhitungan laju deoksigenasi dan reoksigenasi di sungai tersebut. Berdasarkan tabel 2 dan 3, rerata nilai laju deoksigenasi adalah 3,54 mg/L lebih kecil dibandingan dengan rerata nilai laju reoksigenasi adalah $38,03 \mathrm{mg} / \mathrm{L}$.

Tabel 2. Nilai laju deoksigenasi (Rd)

\begin{tabular}{lcccc}
\hline Lokasi Pengamatan (Kode) & $\begin{array}{c}\mathbf{K}_{\mathbf{D}} \\
\mathbf{1 / h a r i}\end{array}$ & $\begin{array}{c}\text { KdT } \\
\mathbf{1 / h a r i}\end{array}$ & $\begin{array}{c}\mathbf{L t} \\
\mathbf{m g} / \mathbf{L}\end{array}$ & $\begin{array}{c}\text { Laju Deoksigenasi } \\
\text { mg/L.hari }\end{array}$ \\
\hline GP01 & 1,42 & 1,71 & 1,86 & 3,19 \\
GP02 & 1,56 & 1,87 & 2,87 & 5,36 \\
GP03 & 1,56 & 1,87 & 1,58 & 2,94 \\
GP04 & 1,61 & 1,93 & 1,38 & 2,67 \\
\hline Rerata & 1,54 & 1,86 & 1,92 & 3,54 \\
\hline
\end{tabular}


Tabel 3. Nilai laju reoksigenasi (rR)

\begin{tabular}{lcccc}
\hline Lokasi Pengamatan (Kode) & $\begin{array}{c}\text { Kr } \\
\text { 1/hari }\end{array}$ & $\begin{array}{c}\text { KrT } \\
\mathbf{1 / h a r i}\end{array}$ & $\begin{array}{c}\text { D } \\
\text { mg/L }\end{array}$ & $\begin{array}{c}\text { Laju Reoksigenasi } \\
\text { mg/L.hari }\end{array}$ \\
\hline GP01 & 12,25 & 13,05 & 3,22 & 41,98 \\
GP02 & 18,76 & 11,43 & 3,24 & 44,71 \\
GP03 & 19,29 & 8,86 & 1,59 & 32,77 \\
GP04 & 26,87 & 16,24 & 1,18 & 33,75 \\
\hline Rerata & 12,39 & 2,31 & 43,30 & 38,30 \\
\hline
\end{tabular}

\subsection{Proses Degradasi Bahan Organik (Auto-Purification)}

Performa sungai dalam mendegradasi bahan organik secara alami dipengaruhi oleh banyaknya paparan bahan organik dalam hal ini BOD, laju deoksigenasi, dan laju reoksigenasi. Adapun grafik pemurnian alami disajikan pada Gambar 2.

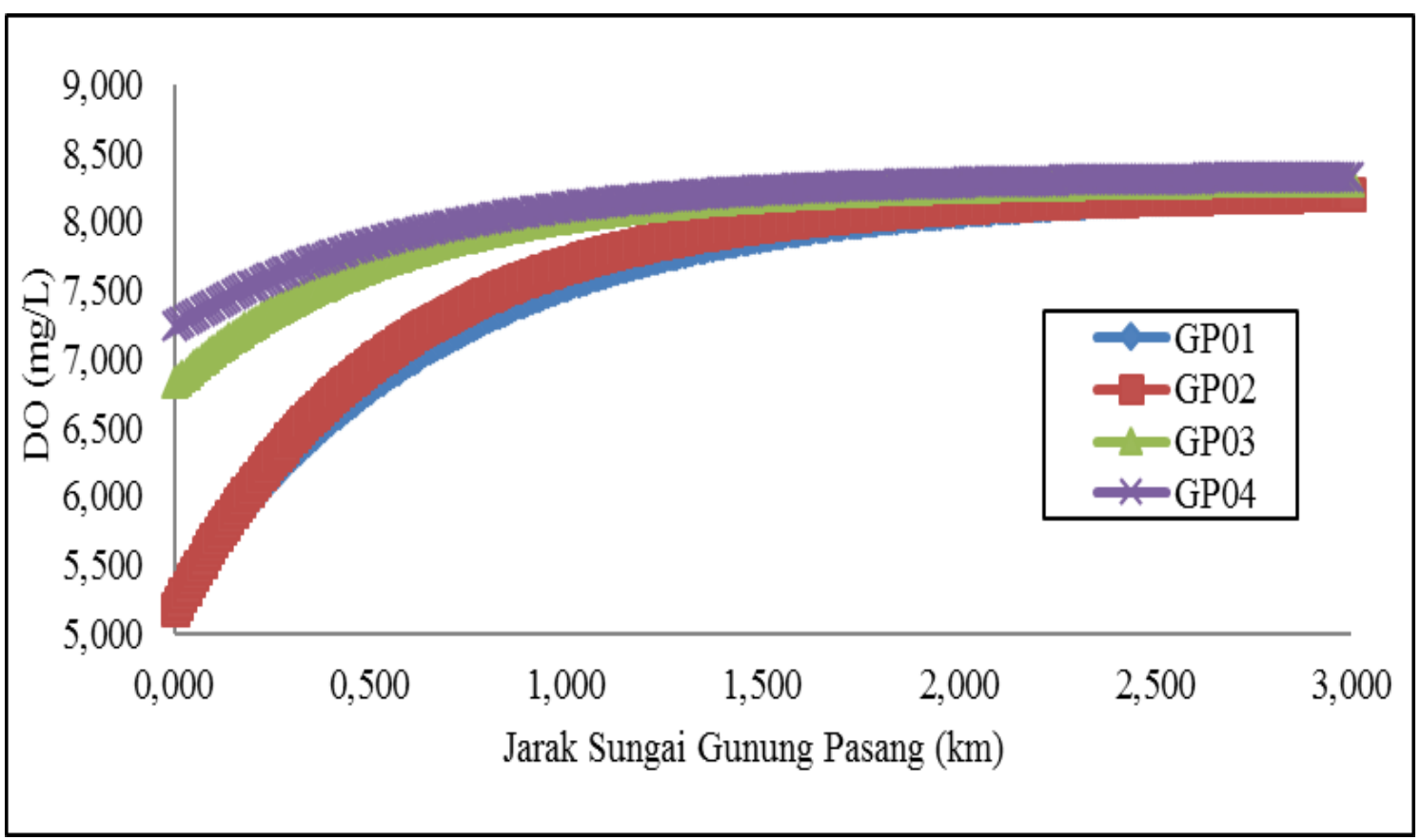

Gambar 2.

Grafik Pemurnian Alami Sungai Gunung Pasang

Pemurnian alami pada Sungai Gunung Pasang cenderung miningkat sejauh jarak $3 \mathrm{~km}$. Asumsi tersebut didukung oleh grafik pada Gambar 2. Kondisi perubahan konsentrasi bahan pencemar organik yang cenderung menurun pada jarak tertentu mengindikasikan terjadinya pemurniaan secara alami. Konsekuensi tersebut timbul akibat perubahan nilai oksigen terlarut yang mendukung terjadinya dekomposisi bahan organik secara biokimia. Sejalan dengan fenomena tersebut Arbie et al, (2015), perubahan kadar oksigen terlarut yang akan berkonstribusi terhadap pertumbuhan mikroorganisme aerob pada jarak tertentu akan menurunkan konsentrasi bahan pencemar pada perairan. Kondisi tersebut terjadi apabila 
tidak ada masukan bahan pencemar pada ungai.

Merujuk pada Gambar 2 diketahui bahwa setiap titik pantau tidak mengalami penurunan oksigen terlarut. Hal tersebut menunjukkan bahwa Sungai Gunung Pasang tidak mengalami kondisi kritis dikarenakan rata-rata nilai laju reoksigenasi $\left(\mathrm{r}_{\mathrm{R}}\right)$ lebih besar dibandingkan dengan laju deoksigenasi $\left(r_{D}\right)$. Rata-rata nilai $r_{R}$ Sungai Gunung Pasang sebesar 43,30/hari, sedangkan rata-rata nilai $r_{D}$ sebesar 3,54/hari. Hal tersebut menunjukkan bahwa peningkatan oksigen pada Sungai Gunung Pasang lebih besar dari penurunan oksigen. Hal tersebut menunjukkan beban pencemaran yang masuk ke badan pada titik GP01 - GP04 tidak berdampak besar pada perubahan kualitas air Sungai Gunung Pasang. Tingginya konstanta reoksigenasi pada titik lokasi pengambilan, mengakibatkan penyebaran oksigen berlangsung cepat dalam pertukaran oksigen dari atmosfer ke dalam sungai. Konsekuensi yang timbul dari fenomena tersebut adalah berlansungnya penambahan oksigen dan tidak terjadi penurunan oksigen. Selain itu, Faktor hidrolik sungai seperti kedalaman, kecepatan aliran, dan turbulensi juga memengaruhi pemurnian alami air sungai (Arbie et al, 2015). Pada dasarnya pemurniaan alami oleh sungai bergantung pada kondisi sungai secara alami atau dengan kata lain disebut sebagai purifikasi alami yang terbentuk pada sungai, karakteristik bahan pencemar yang masuk ke badan air, dan banyak sedikitnya air yang mengalir atau tertampung.

\subsection{Kapasitas Maksimum Beban Pencemaran Sungai Gunung Pasang (Daya Tampung)}

Pemodelan Streeter-Phepls terbatas menjadi 2 fenomena yaitu deoksigenasi dan reoksigenasi. Oksigen terlarut (OT) mengindikasikan sebaran oksigen pada badan air yang digunakan sebagai salah satu dasar penilaian kondisi kualitas perairan. Nilai DO bersifat fluktuatif bergantung pada zat pencemar organik (BOD) dan pemurnian alami sungai. Konsentrasi zat pencemar yang dibuang ke sungai dapat menurunkan kandungan DO akibat konsumsi oleh mikroba untuk mendegradasi bahan organik (deoksigenasi). Di sisi lain, kondisi profil hidrolik sungai yang membentuk relief tertentu menimbulkan terjadinya suplai oksigen dari atmosfer akibat turbulensi pada aliran air sehingga kandungan DO di perairan sungai meningkat (reoksigenasi). Kecepatan pengurangan oksigen terlarut dinyatakan dalam laju deoksigenasi $\left(r_{D}\right)$ dan kecepatan penambahan oksigen terlarut pada perairan dinyatakan dengan laju reoksigenasi $\left(\mathrm{r}_{\mathrm{R}}\right)$. Data hasil perhitungan DO Lapang dan DO model dapat dilihat pada Gambar 3. Berdasarkan hasil pematauan secara langsung pada lokasi studi menunjukkan bahwa sungai tersebut tidak difungsikan sebagai sumber air baku. Sungai Gunung Pasang dimanfaatkan sebagai sarana rekreasi oleh sebab itu baku mutu parameter BOD yang dijadikan untuk penetapan daya tampung beban pencemarannya yakni kelas II. Nilai ambang batas BOD PP nomor 82 Tahun 2001 . 


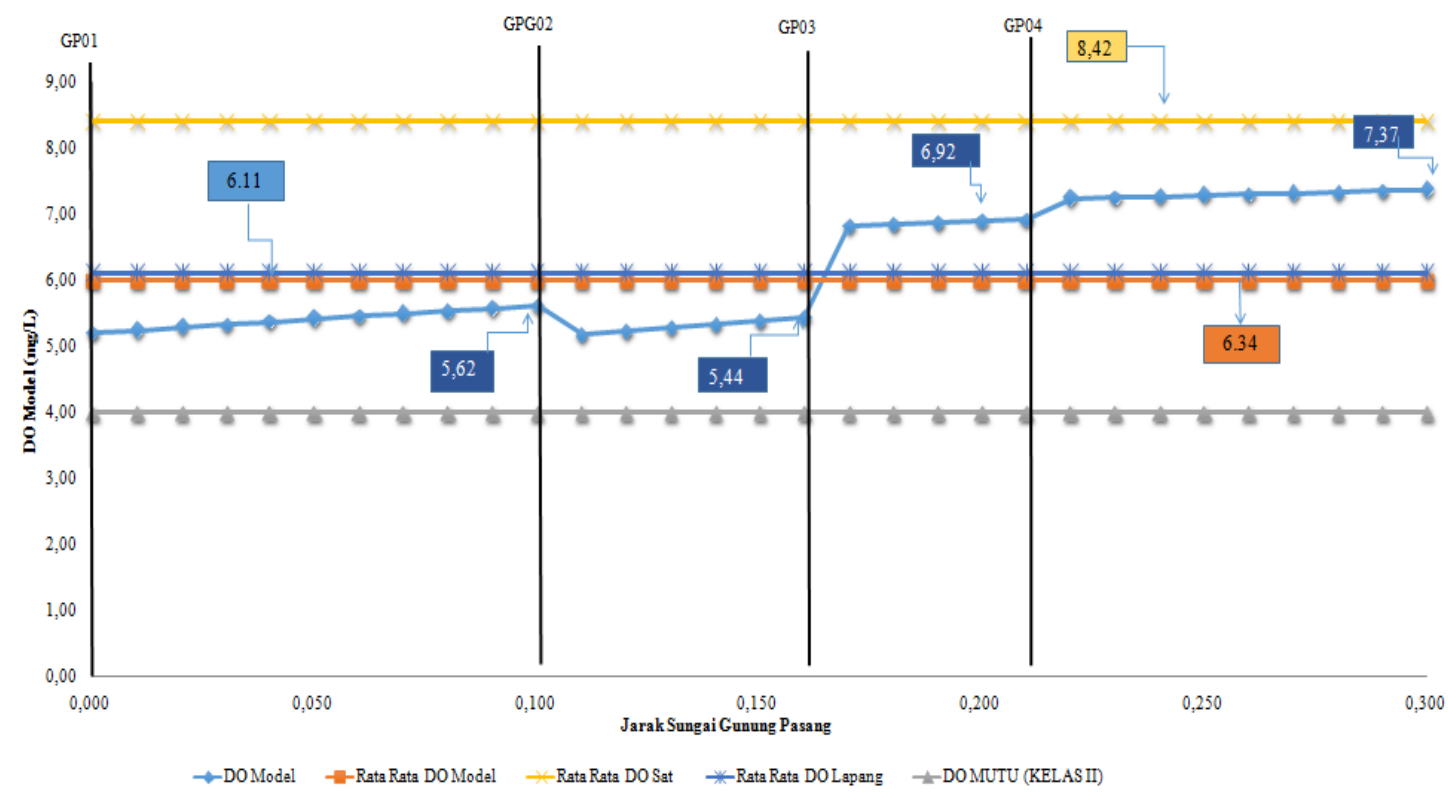

Gambar 3.

Profil nilai DO Sungai Gunung Pasang

Rerata nilai kandungan DO Lapang adalah 6,12 mg/L. Kemudian, rerata nilai BOD aktual Sungai Gunung Pasang yakni 0,68 mg/L. Adapun penetapan jumlah bahan organik atau BOD yang masih diijinkan dibuang ke badan air adalah berdasarkan seilish BOD baku mutu kelas II dan BOD yang diukur di lapang. Sungai Gunung Pasang Segmen Desa Suci Kecamatan Panti Kabupaten Jember. Berdasarkan Peraturan Pemerintah Republik Indonesia Nomo 82 Tahun 2001 tentang Pengelolaan Kualitas Air dan Pengendalian Pencemaran Air sesuai dengan peruntukannya termasuk dalam baku mutu air kelas II. Nilai BOD adalah 0,24 mg/L. Nilai tersebut dipakai untuk menjelaskan daya tampung beban pencemaran sungai yang masih tersisa jika bernilai positif. Perhitungan tersebut diperoleh nilai sebesar 2,17 $\mathrm{kg} / \mathrm{hari}$. Hal tersebut dapat diartikan bahwa Sungai Gunung Pasang walaupun menerima beban pencemar tetapi masih berada pada kondisi aman sebagai peruntukan baku mutu air kelas
II dan masih mampu menampung beban pencemar sebesar $2,17 \mathrm{~kg} / \mathrm{hari}$.

\section{SIMPULAN DAN SARAN}

\section{1 Simpulan}

Hasil kajian di Sungai Gunung Pasang pada titik pengamatan atau pemeriksaan (GP 01 - 04) memiliki nilai rata - rata beban pencemaran sebesar 6,32 kg/hari. Kemudian, rerata nilai laju deoksigenasi Sungai Gunung Pasang yakni 3,54 mg/L.hr. Kemudian, rerata nilai laju reoksigenasi sebesar 43,30 mg/L.hari. Rerata kandungan BOD sisa adalah $0,68 \mathrm{mg} / \mathrm{L}$. BOD sisa akan dikonversi dalam beban pencemaran maksimum. Adapun beban pencemaran maksimum Sungai Gunung Pasang sebesar 2,17 kg/hari. Hal tersebut dapat diartikan bahwa walaupun menerima beban pencemaran tetapi masih berada pada kondisi aman dan masih mampu menerima beban pencemar senilai dengan beban pencemaran maksimum. 


\subsection{Saran}

Perlu dilakukan pemantauan secara berkala terkait daya tampung Sungai Gunung Pasang karena adanya faktor perubahan debit dan perubahan jumlah pencemaran yang masuk ke sungai.

\section{DAFTAR PUSTAKA}

Arbie, R.R., Nugraha, W.D., Sudarno. 2015. Studi kemampuan self purification pada Sungai Progo ditinjau dari parameter organik DO dan BOD (point source: limbah sentra tahu Desa Tuksono, Kecamatan Sentolo, Kabupaten Kulon Progo, Provinsi D.I. Yogyakarta). Jurnal Teknik Lingkungan, 4(3): 1-15. http://ejournals1.undip.ac.id/index.php/tlingku ngan

Abukilla, A.F. 2012. Assessment of natural self-restoration of the water of Al-Mahmoudia Canal, Western part of Nile Delta, Egypt. Irrigation and Drainage System Engineering, 1(3): 1-10. doi: $\quad 10.4172 / 2168$ 9768.1000104

Dinas Kebersihan dan Lingkungan Hidup (DLH) Kabupaten Jember. 2007. Laporan: Status Lingkungan Hidup Daerah Kabupaten Jember. Jember.

Heidar, H., Ali, W., Haydar, S. 2013. A review of dissolved oxygen and biochemical oxygen demand model for large river. Pakistan Journal of Engineering and Applied Science, 12:127-142.

Huang, J., Yin, H., Chapra, S.T., Zhou, Q. 2017. Modelling dissolved oxygen depression in an urban river in China. Water, 9(520): 1 - 19.https://doi.org/10.3390/w907 0520 .

Keputusan Menteri Negara Lingkungan Hidup Nomor 110 Tahun 2003 (Kepmen LH No. 110/2003). "Pedoman Penetapan Daya Tampung Beban Pencemaran Air pada Sumber Air Metoda Streeter-Phelps". Jakarta.

Marganingrum, D., Djuwansah, M.R., Mulyono, A. 2018. Penilaian daya tampung Sungai Jangkok dan Sungai Ancar terhadap polutan organik. Jurnal Teknologi Lingkungan, 19(1): 71-80.

https://doi.org/10.29122/jtl.v19i 1.1789

Pangestu, R., Riani, E., Effendi, H. 2017. Estimasi beban pencemaran point source dan limbah domestik di Sungai Kalibaru Timur Provinsi DKI Jakarta, Indonesia. Jurnal Pengelolaan Sumberdaya Alam dan Lingkungan, 7(3):219226.https://doi.org/10.29244/jpsl .7.3.219-226.

Pradana, H.A., Novita, E., Wahyuningsih, S.,Pamungkas, R. 2019. Analysis of deoxygenation and reoxygenation rate in Indonesia River (a case study: Bedadung River East Java). IOP Conf. Series: Earth and Environmental Science, 243: 1 9.doi:10.1088/17551315/243/1/012006.

Pradana, H.A., Novita, E., Andriyani, I.,Purnomo, B.H. 2020. Land use impact to water quality in Bedadung River, Indonesia. IOP Conf. Series: Earth and Environmental Science, 447: 18.doi:10.1088/1755- 
1315/477/1/012015.

Peraturan Pemerintah Republik Indonesia Nomor 82 (PP No. 82 2001). 2001. "Pengelolaan Kualitas Air dan Pengendalian Pencemaran Air". Jakarta.

Peraturan Menteri Lingkungan Hidup Nomor 1 (Permen LH No. 1 2010). 2010. "Tata Laksana Pengendalian Pencemaran Air". Jakarta.

Putra, I.K.A., Suyasa, I.W.B., Dharma, I.G.B. 2017. Penetapan daya tampung beban pencemaran Tukad Mati di Kabupaten Badung dengan model Qual2Kw 5.1. Ecotrophic, 11(2): 8793.https://doi.org/10.24843/EJE S.2017.v11.i02.p11.

Rahayu, Y., Juwana, I., Marganingrum, D. 2018. Kajian perhitungan beban pencemaran air sungai di Daerah Aliran Sungai (DAS) Cikapundung dari Sektor Domestik. Jurnal Rekayasa Hijau, 1(2): 6171.https://doi.org/10.26760/jrh.v 2i1.2043.

Standar Nasional Indonesia (SNI) No. 6989.72. 2009. "Air dan Air Limbah - Tata Cara Uji Oksigen Terlarut Secara Biologi”. Jakarta.

Standar Nasional Indonesia (SNI) No. 8066. 2015. "Tata Cara Pengukuran Debit Aliran Sungai dan Saluran Terbuka Menggunakan Alat Ukur Arus dan Pelampung". Jakarta.

Sinaga, E.LR, Muhtadi, A., Bakti, D. 2018. Profil suhu, oksigen terlarut, dan $\mathrm{pH}$ secara vertikal selama 24 jam di Danau Kelapa Gading Kabupaten Asahan Sumatera Utara. Omni-Akuatika,
12(2): 114-124.

Sugianti, Y, Astuti, L.P. 2018. Respon oksigen terlarut terhadap pencemaran terlarut terhadap pencemaran dan pengaruhnya terhadap keberadaan sumber daya ikan di Sungai Citarum. Jurnal Teknologi Lingkungan, 19(2): 203-212. https://doi.org/10.29122/jtl.v19i 2.2488

Wahyuningsih, S., Novita, E., Ningtias, R. 2019. Laju deoksigenasi dan laju reaerasi Sungai Bedadung Segmen Desa Rowotamtu Kecamatan Rambipuji Kabupaten Jember. Jurnal Ilmiah Rekayasa Pertanian dan Biosistem, $\quad \mathbf{7 ( 1 ) :} \quad 1$ 7.https://doi.org/10.29303/jrpb.v 7 i1.97.

Wahyuningsih, S., Novita, E., Afifah, S.N. 2020. Daya tampung beban pencemaran Sungai Sumbertelek Kabupaten Jember menggunakan metode streeterphelps. Jurnal Ilmiah Rekayasa Pertanian dan Biosistem, 8(1):110-

118.https://doi.org/10.29303/jrp b.v8i1.155.

Wang, Y., Zhou, X., Engel, B. 2018. Water environment carrying capacity in Bosten Lake Basin. Journal of Cleaner Production, 199: $\quad 574-$ 583.https://doi.org/10.1016/j.jcle pro.2018.07.202.

Yustiani, Y.M., Wahyuni, S., Alfian, M.R. 2018. Investigationon the deoxygenation rate of water of Cimanuk River, Indramayu, Indonesia. Rayasan J. Chem, 11(2): 475-481 http://dx.doi.org/10.31788/RJC.2 018.1121892 . 
Yustiani, Y.M., Wahyuni, S., Kadir, A.A.A. 2019. Identifikasi nilai laju deoksigenasi di daerah pada penduduk: studi kasus Sungai Cicadas, Bandung. Journal of
Community Based

Environmental Engineering and Management, 3(1): 9-14. http://dx.doi.org/10.23969/jcbee m.v3i1.1496 